\title{
The changing littoral. Anticipation and adaptation to climate change
}

\author{
Yvonne Battiau-Queney ${ }^{1}$
}

Published online: 24 April 2018

(C) Springer Science+Business Media B.V., part of Springer Nature 2018

\section{Introduction}

This special issue gathers a selection of papers presented during Littoral 2016 in Biarritz organized by EUCC-France and the Coastal and Marine Union (EUCC). Entitled "The Changing Littoral. Anticipation and Adaptation to Climate Change" the conference allowed researchers and experts to take stock of scientific knowledge, new tools and methods of studying coastal zones ( 6 keynotes, 6 thematic workshops, 88 oral papers and 28 posters) (Battiau-Queney \& Milon 2017). The conference addressed some fundamental questions about coastal environments and the different ways to reconcile nature and biodiversity conservation and sustainable development. It was also a noteworthy event to help French and European stakeholders present their "savoir-faire" and exchange experiences about the practices and strategies of coastal management. Since decisions today will shape the future littoral, managers and policy makers have to adapt their strategy to the increasing vulnerability of coastal areas and to take account of the possible midand long-term effects of management practices. To do this they need a good knowledge of coastal systems and it is fundamental to disseminate the results of current research amongst managers, policy makers and the general public. Through Littoral 2016, EUCC-France and its partners have contributed to this objective.

Research topics addressed in this special issue

\section{Beach nourishment}

Since marine erosion of beaches involves the export of sand to the sea it seems normal to resort to sand replenishment

Yvonne Battiau-Queney

yvonne.battiau@orange.fr

1 CNRS, UMR 8187, LOG, Laboratory of Oceanology and Geosciences, University of Lille, F 59000 Lille, France to avoid beach depletion. Is it a good solution? Three papers try to answer the question.

Spodar et al. describe an example of beach nourishment in France where managers are often reluctant to adopt such practices of coastal protection, contrary to approach of the United States and other European countries. The sand comes from channel dredging in the Port of Dunkirk and is deposited on the nearby beach bordering a sea dike which protects part of the city of Dunkirk from marine flooding. The paper explains in detail the low energy marine and hydrosedimentary environment of the study area and the large beach replenishment project which was carried out by the Port of Dunkirk a few years ago. A period of $2 \frac{1}{2}$ years of beach surveys, in-situ hydrodynamic measurements and offshore wave and wind statistics assessed the efficiency of the project and to provide an explanation of the morphological impacts along the coast. Only $9 \%$ of sand was lost and mainly redistributed to downdrift sections of the coast. The authors conclude that the Dunkirk beach replenishment operation has been a success with beneficial reuse of clean dredged sand for coastal protection and seaside resort development.

Marinho et al. describe a completely different example of nearshore sand nourishment on the northwest coast of Portugal in a high energy environment. Here the sand is placed not on the subaerial beach but in the subtidal nearshore zone. It comes mainly from the dredging of the Aveiro Harbour navigation channel. A six-years monitoring programme to evaluate short and long term responses in the deposit areas and nearby beaches shows that a great part of the fill sediment is quickly lost and dispersed offshore and in one dumping area at least does not significantly nourishes the closest beach. More systematic surveying and better knowledge of the sediment transport processes are needed before going on this type of subtidal replenishment.

In the Netherlands sand nourishment has been adopted as the main coastal management strategy to maintain the 1990 shoreline position. Brière et al. explain the famous "Sand Motor" approach from the initial project to the final realization 
in 2011with a total sand volume of 21.5 million $\mathrm{m}^{3}$. It is a nature-based coastal protection strategy. The authors present the results of four years monitoring (morphological and ecological development, leisure activities, better knowledge and innovation) and conclude that the Sand Motor has globally a positive impact with $5 \%$ only of sand loss. Nevertheless a longer period of monitoring is necessary to get a complete evaluation. The Dutch savoir-faire acquired with this project could be used in other countries ... provided that huge sand resources are available.

\section{Coastal dunes management}

This is a very important topic since coastal dunes can form in many different regions all over the world. They play a significant role in coastal protection, beach and biodiversity conservation and economic development. The topic was thoroughly addressed during Littoral 2016.

Bezzi et al. describe the case of coastal dunes in the Veneto region (Italy). They give an overview of these coastal dunes based on two geodatabases (Veneto and Po Delta). The authors propose a classification of dunes according to their morphology, vegetation and level of anthropisation. In Veneto - as in the rest of Italy - the beaches and coastal dunes are managed as private properties with severe consequences for beach and dune conservation. The authors highlight the poor management that has led to the generally poor state of dunes in the Veneto region, despite favourable natural conditions for dune development. They propose a simple indicator called "management effectiveness" combining the "human impact" and "active management practices". This study clearly illustrates the fact that good management requires a sound knowledge of processes, but this may not be sufficient without regulations and controls in the field, currently lacking in Italy.

Garcia-Lozano and Pinto explain why natural conditions are not favourable to the formation of dunes along the Catalan coast of Spain. Meanwhile, poorly developed coastal dunes widespread in the early twentieth century have mostly disappeared due to high urbanization and tourism pressures. The authors explore the beach characteristics with conditions required to restore dunes and conclude that 150 Catalan beaches (over 800) could be affected.
3. Integrated coastal zone management

Schernewski et al. present an example of combined coastal protection, realignment and wetland restoration in the southern Baltic, Germany. Despite its scientific interest the programme was not accepted well by the population. The authors try to explain why; a review of the literature and media, and two surveys of beach visitors, inhabitants and wetland visitors, added valuable information to expert interviews.. To avoid such difficulties in future projects they provide recommendations and suggest a pro-active and long term collaborative public relation strategy with a systematic and stepwise approach from initiation to the implementation of the scheme.

Karnauskaitè et al. propose an indicator-based tool to assess the sustainability of ICZM practices. They use the OURCOAST database and apply the tool to 18 thematically different coastal cases of northern Europe. The value, usefulness, but also possible weaknesses of the indicators are thoroughly discussed using different case studies. When applying the tool the role of evaluators is also discussed. The authors conclude that the tool is useful but can be improved by adapting the indicators to the needs of strategic goals of ICZM initiatives.

\section{Risk management}

Umgiesser et al. present an example of applied research concerning the pollution impact of E.coli on a newly planned beach of the Curonian lagoon (Lithunia). They use a 3D hydrodynamic model to measure inputs and laboratory experiments to assess the decay rate of E.coli. The model has been run for a twelve-year simulation in case of breakdown of the sewage system located on the Curonian spit. The study answers the implementation of the Bathing Water Directive (2006/7/EC).

\section{Reference}

Battiau-Queney Y, Milon E (dir.) (2017) Littoral 2016, Biarritz. The Changing Littoral. Anticipation and Adaptation to Climate Change. Proceedings. EUCC-France, Biarritz ISBN: 978-29560890-1-8 